\title{
The Role of Disasters in Investment Arbitration
}

\author{
Rhys Carvosso*
}

The embryonic field of international disaster law (IDL) is coming to be integrated with more entrenched fields and disciplines of international law. This trend is accelerating as evidence mounts of the immense capacity of disasters to disrupt human society. The imperative for these academic forays also grows as scientific research continues to link anthropogenic climate change to natural hazards and extreme weather events of greater intensity and frequency. ${ }^{1}$ Indeed, the number of climate-related and extreme weather events has risen almost $35 \%$ since the 1990 s, culminating with 2850 disasters - claiming over 410,0oo lives and affecting 1.8 billion people worldwide - in the last decade. ${ }^{2}$

One field of international law on which disasters have significant bearing is the protection of foreign investments. Disasters can affect an investment physically or financially, or prompt a host State to implement regulatory measures for the purposes of disaster risk reduction (DRR), response, relief, and recovery. Both these direct impacts and regulatory measures may have legal consequences under the international investment agreements (IIAs) and the rules of arbitral procedure in accordance with which investor-State disputes are typically resolved.

So far, there has been very little academic investigation into the relationship between disasters and investor-State arbitration. ${ }^{3}$ In particular, there is no empirical research which identifies and analyses the past interfaces between investor-State arbitration and disasters. This research would provide a crucial baseline from which to advance normative discussions as to whether the investment arbitration framework is equipped to manage and adapt to

* BA LLB (Hons I) (Syd) LLM (Cantab); Tipstaff at the NSW Court of Appeal, Australia.

1 See 'World Disasters Report 2020' (IFRC, 202O), Chapter $2<$ https://media.ifrc.org/ifrc/world -disaster-report-2020/> last accessed (as any subsequent URL) on 4 May 2021.

2 Ibid., 19.

3 For a rare example, see Leila Choukroune, 'Disasters and international trade and investment law - the state's regulatory autonomy between risk protection and exception justification' in Susan C. Breau and Katja L.H. Samuel (eds), Research Handbook on Disasters and International Law (Edward Elgar 2016) 204. See also Marie Aronsson-Storrier, 'Sendai Five Years On: Reflections on the Role of International Law in the Creation and Reduction of Disaster Risk' (2020) 11 International Journal of Disaster Risk Science 230, 231-232. 
the exigencies of disasters, both present and future. The need for these discussions is particularly acute now, given the extraordinary strain being placed on the framework by the COVID-19 pandemic, and our perilous position on the cusp of a predicted upsurge in climate change-induced disasters.

Accordingly, this article presents such research, by undertaking a comprehensive review of the body of investor-State dispute settlement (ISDS) jurisprudence as it relates to disasters, both in matters of procedure and substance. Section II details the various "entry points" for disasters in the jurisprudence in four subsections. First, it considers how disasters have borne on four issues of procedure, namely on procedural schedules, virtual hearings, the availability of witnesses, and costs orders. Secondly, it turns to consider past interfaces between disasters and an investment tribunal's jurisdiction (especially as to the requisite "legality" of an investment). Thirdly, it outlines their bearing on the merits of investment disputes, in shaping both an investor's claims and a respondent State's pleadings in defence or mitigation. Finally, it addresses the impact of disasters at the enforcement stage. Section III then presents some brief, generalised observations on how disasters have most prevalently impacted investment arbitration so far; and what legal and systemic questions these deepening interfaces are likely to generate in future. Section IV offers a conclusion.

For the purposes of this article, a "disaster" is understood, in line with the International Law Commission's definition in its 2016 Draft Articles on the Protection of Persons in the Event of Disasters, to include 'any calamitous event or series of events resulting in widespread loss of life, great human suffering or distress, mass displacement, or large-scale material or environmental damage, thereby disrupting the functioning of society'. It includes all kinds of biological, geophysical, technological, and human-made hazards, including both rapid and slow-onset events. However, it excludes armed conflicts, in which rules of international humanitarian law apply in the first instance, ${ }^{5}$ though not necessarily to the exclusion of disaster-specific norms. ${ }^{6}$ It also excludes "economic" events such as financial crises per se, mirroring the same taxonomic

4 UN Doc. A/71/10, art. 3(a).

5 Ibid., art. 18(2).

6 Ibid., Commentary on art. 18(2), paras. 8-9, <https://legal.un.org/ilc/texts/instruments/eng lish/commentaries/6_3_2016.pdf >: '[I]n situations of "complex emergencies" where a disaster occurs in an area where there is an armed conflict, ... the rules of international humanitarian law shall be applied as lex specialis, whereas the rules contained in the present draft articles would continue to apply "to the extent" that legal issues raised by a disaster are not covered by the rules of international humanitarian law'. 
distinction drawn in influential IDL instruments. ${ }^{7}$ In any case, there is already ample literature scrutinising the investment jurisprudence in relation to these events (e.g. the Argentine financial crisis), both with a general ${ }^{8}$ and an IDL lens. ${ }^{9}$ IDL-specific analyses of this jurisprudence remain valuable even though the underlying crises fall outside the definitional scope of a "disaster" for two reasons. First, they shed some light on the interpretation and application of the same IIA emergency provisions and customary defences that potentially apply mutatis mutandis in disaster situations. Secondly, they address the possibility that economic crises might arise out of disaster situations.

\section{Entry Points for Disasters in Investment Arbitration}

\subsection{Procedure}

The first set of entry points for disasters in past IsDs jurisprudence concern matters of "procedure". Procedure is understood to encompass rules governing the conduct of proceedings - i.e. how the parties' claims are organised, presented, resolved and enforced by an IsDs tribunal, but not the content of the claims. ${ }^{10}$ I adopt this definition for descriptive convenience, without prejudice to the many theoretical accounts of the distinction between substance and procedure. ${ }^{11}$ The four matters of procedure discussed below are: modifications to procedural schedules, virtual hearings, the availability of witnesses, and costs orders.

$7 \quad$ Ibid., Commentary on art. 3(a), para. 2: 'Subparagraph (a) defines the term "disaster" solely for the purposes of the draft articles. The definition has been delimited so as to properly capture the scope of the draft articles, as established in draft article 1, while not, for example, inadvertently also dealing with other serious events, such as political and economic crises, which may also undermine the functioning of society, but which are outside the scope of the draft articles'.

8 See e.g., William Burke-White and Andreas von Staden, 'Investment Protection in Extraordinary Times: The Interpretation and Application of Non-Precluded Measures Provisions in Bilateral Investment Treaties' (2007) 48 Virginia Journal of International Law 307 .

9 See Ibironke Odumosu-Ayanu, 'International Investment Law and Disasters: Necessity, Peoples, and the Burden of (Economic) Emergencies' in David Caron, Michael Kelly and Anastasia Telesetsky (eds), The International Law of Disaster Relief (CUP 2014) 314.

10 See Robert Kolb, 'General Principles of Procedural Law' in Andreas Zimmermann, Christian Tomuschat and Karin Oellers-Frahm (eds), The Statute of the International Court of Justice: A Commentary (oup 2019) 963, 965-966.

11 See e.g. Malcolm N. Shaw and Shabtai Rosenne, Rosenne's Law and Practice of the International Court 1920-2015, Volume III: Procedure (Brill/Nijhoff 2016) 1047-1052. 


\subsubsection{Amendments to Procedural Schedules}

First, disasters may prompt one or both parties to an investor-State arbitration to seek modifications to the procedural schedule. Many parties have requested the postponement of hearings, extensions to submission deadlines, or even the suspension of proceedings, on grounds that their ability to collect evidence, communicate with witnesses, liaise with counsel, produce documents and/or adequately prepare and present their case, has been adversely affected by a disaster.

Many modifications are adopted by agreement, which naturally obviates the need for adjudication. ${ }^{12}$ However, certain requests are opposed by the other party. For instance, in Glencore Finance v. Bolivia, the Respondent argued that movement restrictions in Bolivia during the COVID-19 pandemic meant it could not access hard copies of relevant documents; and that limitations to telecommunications infrastructure in Bolivia meant it was finding it difficult to communicate with certain witnesses remotely. ${ }^{13}$ On that basis, it sought suspension of the arbitration, or else an 8-week extension to a submission deadline, ${ }^{14}$ both of which the Claimant opposed. Moreover, on rare occasions, tribunal determinations on these requests produce additional procedural disputes. For instance, the Respondent in Vattenfall $v$. Germany (II) sought unsuccessfully to disqualify the tribunal on the basis that, by refusing its COVID 19-motivated requests for extension, it had forced an 'unbearable procedural calendar' on it. ${ }^{15}$

While fact patterns differ, one can discern two trends from the way that ISDS tribunals have dealt with requests for modification of procedural schedules. First, tribunals have almost invariably rejected requests to suspend proceedings

12 See e.g. Resolute Forest Products Inc. v. Government of Canada, PCA Case No. 2016-13, Procedural Order No. 14 on a Further Revised Schedule for the Merits and Damages Phase, 7 May 2020, para. 1.3, in which the parties agreed to postpone their hearing due to COvid-19. See also Rand Investments Ltd. and others v. Republic of Serbia, ICSID Case No. ARB $/ 18 / 8$, Procedural Order No. 8, 3 November 2020; Michael Anthony LeeChin v. Dominican Republic, ICSID Case No. UNCT/18/3, Partial Award on Jurisdiction, 15 July 2020 , paras. $5^{8-60}$.

13 Glencore Finance (Bermuda) Limited v. Plurinational State of Bolivia, PCA Case No. 201639, Procedural Order No. 11, 5 May 2020, para. 8 ("Glencore Finance v. Bolivia").

14 Ibid., para. 4.

15 Vattenfall $A B$ and others v. Federal Republic of Germany II, ICSID Case No. ARB/12/12 ("Vattenfall v. Germany (II)"), Recommendation on the Second Proposal to Disqualify the Tribunal, 6 July 2020, para. 141. Among other things, it argued that its quantum expert team working remotely in Texas had not been able to access necessary files due to a "stay at home" order (para. 142). 
entirely. ${ }^{16}$ While appreciating the difficulties engendered by the pandemic, they have considered that, on the facts presented to them, it remains feasible for the requesting party to continue to prepare submissions and/or participate in the arbitral process, even if with greater difficulty. ${ }^{17}$ As a result, tribunals have opted to grant extensions to submission deadlines and to postpone hearings, but not to indefinitely suspend proceedings. The one tribunal to grant an order for suspension only did so on condition that one party undertook not to prejudice the opposing party's rights in arbitration. ${ }^{18}$ In this way, tribunals have not allowed disasters to be used as a carte blanche justifying any requested procedural concession. ${ }^{19}$

Secondly, in terms of their methodology when determining whether to grant requests for modification, tribunals lie on a spectrum ranging from a pragmatic "common-sense" approach at one end, to a formalistic legal calculus at the other. Some tribunals have been careful to set out the legal framework in which their determination must be made - e.g., the duties of equal treatment of the parties and avoiding 'unnecessary delay and expense and to provide a fair and efficient process' under the 2010 UNCITRAL Rules, ${ }^{20}$ or the residual discretion to control procedure in Article 44 of the ICSID Convention. ${ }^{21}$ For instance, the tribunal in Sumrain v. Kuwait treated its Article 44 discretion as entitling it

16 See e.g. Glencore Finance v. Bolivia (n 13) para. 17; The Estate of Julio Miguel OrlandiniAgreda and Compañía Minera Orlandini Ltda. v. Plurinational State of Bolivia, PCA Case No. 2018-39, Procedural Order No. 7, 10 April 2020, paras. 37-39 ("OrlandiniAgreda v. Bolivia").

17 Orlandini-Agreda v. Bolivia (n 16) paras. 37-39.

18 Ayat Nizar Raja Sumrain and others v. State of Kuwait, ICSID Case No. ARB/19/20, Decision on Request for Suspension of Proceedings and on Request for Provisional Measures, 23 April 2020, para. 23 (Sumrain v. Kuwait).

19 See also Gabriel Resources Ltd. and Gabriel Resources (Jersey) v. Romania, ICsid Case No. ARB $/ 15 / 31$, Procedural Order No. 31, 4 May 2020, para. 8, in which the Claimant's request for a 2-week filing extension, due to disruptions caused to its legal team by CoviD-19 emergency shutdowns, was rejected on the basis that the Claimant's legal team had had sufficient time to prepare; and B-Mex, LLC and others v. United Mexican States, ICSID Case No. ARB(AF)/16/3, Procedural Order No. 2, 1 February 2018, in which the Tribunal rejected the Respondent's request to 'postpone completion of its diligent search for responsive documents indefinitely' after an earthquake in September 2017 in Puebla which caused over 300 casualties. Although the earthquake had prompted the closure of offices where departmental archives were ordinarily stored and the removal of the archives to various other temporary locations, the Tribunal considered that the documents remained accessible, even if not by regular means, and that 'normal' access would soon be restored.

20 Glencore Finance v. Bolivia (n 13) para. 17.

21 Sumrain v. Kuwait ( $\mathrm{n}$ 18) para. 8; Convention on the Settlement of Disputes between States and Nationals of Other States, 18 March 1965, art. 44 ("ICSID Convention"). 
to suspend proceedings 'upon the showing of good cause'.22 Other tribunals have not articulated any legal basis for their decision. ${ }^{23}$ Indeed, in one decision, when one party based its request for a filing extension on the doctrine of force majeure under public international law, ${ }^{24}$ the tribunal declined to entertain the argument, ${ }^{25}$ instead reaching a pragmatic and 'socially responsible' solution based on 'practice in other proceedings. ${ }^{26}$

\subsubsection{Virtual Hearings}

Secondly, the physical and/or regulatory impacts of disasters may also necessitate "virtual" hearings and conferences between the tribunal and the parties. While earlier disasters occasionally prompted the use of virtual conferences, ${ }^{27}$ the CoviD-19 pandemic has thrust them into ubiquity. ${ }^{28}$ Lockdown measures and travel restrictions worldwide have resigned arbitrators, parties, and counsel to remote working arrangements. The arbitration community has attempted to surmount these difficulties by recourse to 'the enhanced use of technology, including greater reliance on teleconference and videoconference facilities. ${ }^{29}$ Arbitral institutions also hastily published protocols to assist parties with virtual hearings. ${ }^{30}$ While institutional responses have so far been

\footnotetext{
$22 \quad$ Ibid.

23 See eg Orlandini-Agreda v. Bolivia (n 16); Gabriel Resources v. Romania (n 19).

24 Orlandini-Agreda v. Bolivia (n 16) paras. 9-12.

25 Ibid., para. 39: '[T] he Tribunal does not need to rule or opine on the existence or not of force majeure as a legal matter'.

26 Ibid., paras. 38, 40.

27 For instance, in Hochtief Aktiengesellschaft v. Argentine Republic, ICsID Case No.
} ARB/o7/31, Award, 21 December 2016, para. 6, the Tribunal recalled a first procedural meeting in April 2010 in which the President of the Tribunal participated by video link, being unable to attend in person, having been 'prevented from flying by [the]volcanic ash cloud' caused by the Eyjafjallajökull volcano in Iceland. Similarly, an impending hurricane expected to disrupt the east coast of the US prompted the ad hoc Committee in SGS v. Paraguay to hold a session with the parties by telephone conference rather than in person in Washington DC: SGS Société Générale de Surveillance S.A. v. Republic of Paraguay, ICSID Case No. ARB/o7/29, Decision on the Continued Stay of Enforcement of the Award, 22 March 2013, para. 21.

28 See e.g. Omega Engineering LLC and Oscar Rivera v. Republic of Panama, ICSID Case No. ARB $/ 16 / 42$, Procedural Order No. 4, 6 October 2020, paras. 4-5; Gran Colombia Gold Corp. v. Republic of Colombia, ICsid Case No. ARB/18/23, Procedural Order No. 7, 21 September 202O, para. 4.

29 Chester Brown, Mark McNeill, and Jeremy Sharpe, 'First Impressions of a Virtual Hearing at ICSID' (2020) 35(1-2) ICSID Review 214, 214.

30 See ICSID, 'Brief Guide to Online Hearings' (ICsid News Release, 24 March 2020), $<$ https://icsid.worldbank.org/news-and-events/news-releases/brief-guide-online -hearings-icsid>; International Chamber of Commerce, 'Guidance Note on Possible 
ad hoc, as disasters continue to proliferate in coming years and these technologies become a permanent fixture in arbitral practice, institutionalised solutions such as re-drafted arbitral rules may eventuate.

Rarely, virtual hearings have been contentious. In Landesbankv. Spain, ${ }^{31}$ the Respondent applied to disqualify the members of the Tribunal under Article 57 of the ICSID Convention, for a 'manifest lack' of moral character and impartiality. One ground for its application was that the tribunal had decided to change the format from in-person to virtual without valid grounds. ${ }^{32}$ In particular, it doubted the validity of one arbitrator's reason for being unable to travel from Costa Rica to The Hague for the hearing, claiming that travel was 'perfectly feasible' and 'easy, in fact', notwithstanding global travel restrictions imposed during the CoviD-19 pandemic. ${ }^{33}$

The arbitrators explained that their decision had factored in the 'unprecedented challenges' of the pandemic along with the requirements of due process and the obligation conduct proceedings as expeditiously as possible. ${ }^{34}$ They cited the unpredictability of travel restrictions as one of the factors influencing their risk assessment. ${ }^{35}$ The Chair of the ICsID Administrative Council, deciding the matter, opined that 'the Tribunal itself is best placed to assess and balance these risks and considerations'; ${ }^{36}$ and that its decision to hold a virtual hearing did not evince any lack of moral character 'given the extraordinary circumstances and the multiple uncertainties created by the CoviD-19 pandemic. ${ }^{37}$ That the Respondent disagreed with the tribunal's risk assessment did not justify their disqualification.

Measures Aimed at Mitigating the Effects of the COVID-19 Pandemic' <https://icc wbo.org/publication/icc-guidance-note-on-possible-measures-aimed-at-mitigating -the-effects-of-the-covid-19-pandemic/>; H KIAC, 'Guidelines for Virtual Hearings' (Press Release, 15 May 2020), <https://www.hkiac.org/news/hkiac-guidelines-virtual-hearings >. Landesbank Baden-Württemberg and others v. Kingdom of Spain, ICSID Case No. ARB / 15/45, Decision on the Second Proposal to Disqualify All Members of the Tribunal, 15 December 2020.

$32 \quad$ Ibid., para. 56 .

33 Ibid., para. 45 .

34 Ibid., para. 94.

35 Ibid., paras. 97-99.

$36 \quad$ Ibid., para. 137 .

Ibid. 


\subsubsection{Availability of Witnesses}

Disasters have also affected the availability of witnesses. In Lao Holdings $v$. $L a o s,{ }^{38}$ the Claimants requested leave to substitute their quantum expert for another at an upcoming hearing. Their original expert had been forced to 'evacuate their home through intense smoke and flying embers' created by a 'massive wildfire' in his area. ${ }^{39}$ The Claimants argued that because the expert had to be 'personally involved in the clean-up and repair process' and suffered 'emotional stress', he was 'incapable of preparing for and participating in' the hearing. ${ }^{40}$ The Respondent objected on grounds, inter alia, that photographic evidence showed minimal damage to the expert's house and that the justification was thereby 'false'.

The Tribunal, turning to Articles 5.5 and 8.1 of the IBA Rules of Evidence as well as its previous procedural orders, ${ }^{41}$ noted that where a party-appointed expert whose appearance has been requested at a hearing 'fails without a valid reason to appear', the tribunal 'shall disregard' that expert's written testimony 'unless in exceptional circumstances' the Tribunal decides otherwise. ${ }^{42}$ (An identical standard applies to fact witnesses under the IBA Rules. ${ }^{43}$ ) On the facts, the tenuous nature of the evidence on both sides precluded the tribunal from deciding whether there was 'valid reason'. The tribunal hence deferred the quantum phase of the hearing, ostensibly in the hope that if a quantum phase were eventually necessary, the original expert would be available to appear. Ultimately, though, the claims failed on the merits, ${ }^{44}$ and so the tribunal was not required to adjudicate this issue further.

Nonetheless, in principle, it is conceivable that the personal, health, financial or logistical consequences of a disaster on a witness, if sufficiently evidenced, may constitute a 'valid reason' not to appear, so as to preserve their testimony. ${ }^{45}$

38 Lao Holdings N.v. v. Lao People's Democratic Republic $I$, ICSID Case No. ARB(AF)/12/6, Procedural Order No. 13, 31 July 2018.

$39 \quad$ Ibid.

$40 \quad$ Ibid.

41 Procedural Order No. 1, Section 15.10, provided: 'The Tribunal may disregard the testimony of a witness or expert called to testify at the hearing who fails to appear at the hearing without justified reasons'.

42 See IвA Rules on the Taking of Evidence in International Arbitration, 29 May 2010, art. 5.5 ("гвА Rules"). While the гвA Rules are non-binding, parties typically agree that tribunals should have regard to them for evidentiary matters.

43 Ibid., art. 4.7.

44 Lao Holdings N.v. v. Lao People's Democratic Republic $I$, ICSID Case No. ARB(AF)/12/6, Award, 6 August 2019 .

45 This does not necessarily mean that the testimony will be afforded significant weight: see Chester Brown and Patrick Still, 'The Status of the Testimony of the Non-Appearing 
Future treatment of this scenario, though, will likely follow the parameters of recent jurisprudence. First, the relevant consequence will more likely justify non-appearance if it is unforeseeable and beyond the party's or witness's control. ${ }^{46}$ This reflects recent decisions in which ill-health ${ }^{47}$ and death ${ }^{48}$ have been regarded sufficient; a practical inability to make necessary travel and visa arrangements due to border restrictions, flight scarcities or visa office closures would also likely qualify. But disasters will not provide a carte blanche justifying non-appearance, as the exercise of the discretion is fact-specific; "control" remains the conceptual touchstone. A circumstance within a party's or witness's control, even in a disaster context, will thus not qualify. Finally, tribunals may order the use of videoconferencing in lieu of appearance. ${ }^{49}$

\subsubsection{Costs Orders}

Finally, disasters may also bear upon advances for costs. In the first instance, it may prompt a party to seek a costs order, or form the basis of a party's submission to that end. In BSG Resources $v$. Guinea, the Respondent argued that the Claimant should pay all costs advances in the proceedings, in part because the Ebola epidemic in Guinea had placed the State's financial situation under 'increasing strain'. ${ }^{0}$ The Claimant argued that this financial strain was irrelevant, because the Respondent was not arguing that it could not cover the costs of arbitration, but that the money would be better spent tackling the epidemic. ${ }^{51}$ The Tribunal accepted that the Ebola crisis had 'caused significant losses to the economy and hence to fiscal resources ... [and] considerably reduced the development and growth perspectives of the country'.52

Witness in International Arbitration' (2020) 35(1-2) ICSID Review 369, 395, citing Tradex Hellas SA v Republic of Albania, ICSID Case No ARB/94/2, Award, 29 April 1999, para. 186; Sempra Energy International v Argentine Republic, ICSID Case No ARB/O2/16, Award, 28 September 2007, para. $15^{8}$.

46 Nathan O'Malley, Rules of Evidence in International Arbitration (Routledge 2019) 135 .

47 Compania de Aguas del Aconquija sA and Vivendi Universal sA v. Argentine Republic (II), ICSID Case No. ARB/97/3, Award, 20 August 2007, para. 2.7.8; WNC Factoring Limited v Czech Republic, PCA Case No. 2014-34, Award, 22 February 2017, paras. 23-26.

48 Quiborax SA, Non-Metallic Minerals SA and Allan Fosk Kaplun. v. Plurinational State of Bolivia, ICSID Case No. ARB /o6/2, Award, 16 September 2015, paras. 93-97.

49 See IвA Rules (n 42) art. 8.1; see also Crystallex International Corporation v Bolivarian Republic of Venezuela, ICSID Case No. ARB(AF)/11/2, Award, 4 April 2016, para. 109 ("Crystallex v. Venezuela").

BSG Resources Limited (in administration), BSG Resources (Guinea) Limited and BSG Resources (Guinea) SÀRL v. Republic of Guinea ("BSG Resources v. Republic of Guinea"), ICSID Case No. ARB/14/22, Procedural Order No. 3, 25 November 2015, para. 14.

$5^{1} \quad$ Ibid., para. 40.

$5^{2} \quad$ Ibid., para. 68. 
Considering that this provided 'good cause' to depart from the principle of equal costs, ${ }^{53}$ it ordered the Claimant to bear $75 \%$ of the costs advances. ${ }^{54}$ In a subsequent decision two years later, the tribunal overturned the order, finding that, since the Ebola crisis had abated and Guinea's GDP had increased, its economy was no longer under the 'exceptional strain' necessary to justify departure from the principle of equal costs. ${ }^{55}$

Conversely, disasters may affect a party's ability to comply with a costs order. The proceedings in Fischer v. Czechia were terminated due to the Claimant's failure to pay the required advances for costs. ${ }^{56}$ The Claimant had requested to 'suspend the proceedings for at least three months due to the special circumstances created by the CoviD-19 pandemic'.57 However, the Tribunal rejected this submission and terminated the proceedings without prejudice. ${ }^{58}$

\subsection{Jurisdiction and Admissibility}

Disasters have also, if only implicitly so far, problematised the establishment of an ISDS tribunal's jurisdiction. In particular, the jurisdictional requirement of "legality" of an investment may implicate a State's disaster law and policy. Many IIAs include "in accordance with domestic law" clauses, either within the definition of investment, ${ }^{59}$ or as a standalone clause. ${ }^{60}$ These clauses typically require that an investment have been "made" or "acquired" in accordance with a host State's law in order to fall within the ambit of the IIA's protection. Generally, tribunals assess legality at the time of investing as a jurisdictional objection, meaning a tribunal lacks jurisdiction or competence over illegally made investments. ${ }^{61}$ Certain other tribunals have treated it as an admissibility

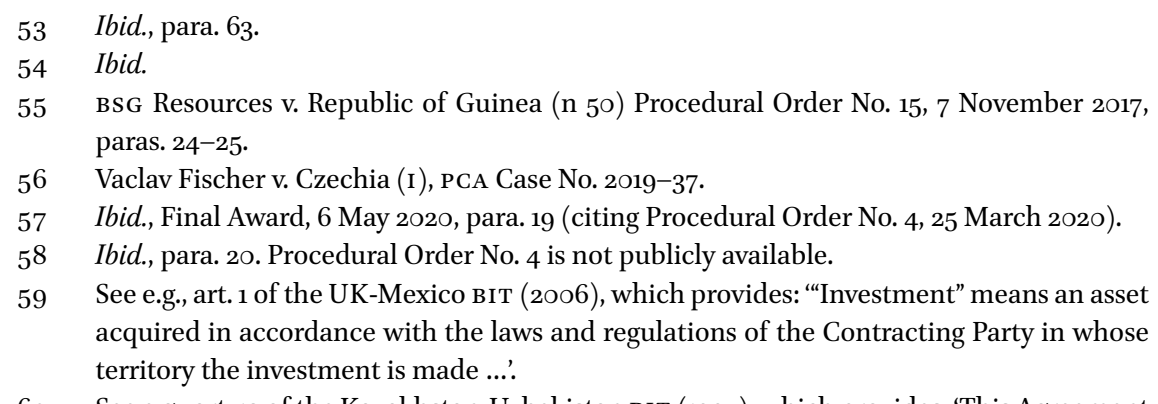

$60 \quad$ See e.g., art. 12 of the Kazakhstan-Uzbekistan BIT (1997), which provides: 'This Agreement shall apply to investments within the territory of one Contracting Party's State, made in compliance with its legislation by investors from the other Contracting Party's State, regardless of whether they were made before or after the entry into force of this Agreement'.

61 See e.g., Inceysa Vallisoletana, S.L. v. Republic of El Salvador, ICSID Case No. ARB/o3/26, Award, 2 August 2006, paras. 248, 339(2) ("Inceysa v. El Salvador"); Desert Line Projects LLC v. The Republic of Yemen, ICSID Case No. ARB/05/17, Award, 6 February 2008, paras. 
bar. ${ }^{62}$ The jurisdictional approach has prevailed even when the relevant IIA does not include an express legality clause. ${ }^{63}$

Jurisprudence indicates that the violation must be of a 'fundamental law' of the hostState, ${ }^{64}$ or at least of a particular subject matter (e.g. foreign investment law). ${ }^{65}$ Recently, in Cortec v. Kenya, the tribunal held that Kenyan environmental and planning laws were sufficiently 'fundamental' that the investor's failure to comply with those laws when acquiring a mining licence warranted a finding of no jurisdiction. ${ }^{66}$ Importantly, the relevant statutory prerequisites for obtaining a licence (including to conduct an environmental impact assessment) were designed to protect an area of 'special vulnerability' ${ }^{67}$

Cortec $v$. Kenya is significant from an IDL perspective for three reasons. First, a State could likely now argue, within the parameters set by Cortec, that an investor who knowingly failed to conduct an EIA mandated under domestic law before investing in a disaster-prone area lacked a valid "investment" for the purposes of an IIA. This is because the tribunal accepted that EIA requirements in domestic law come within the scope of the legality requirement.

113-116 ("Desert Line v. Yemen”); Tokios Tokelés v. Ukraine, ICSID Case No. ARB/o2/18, Decision on Jurisdiction, 28 June 2004, para. 84; Alasdair Ross Anderson et al. v. The Republic of Costa Rica, ICSID Case No. ARB(AF)/o7/3, Award, 19 May 2010, para. 59. For a critique of this prevailing approach, see Zachary Douglas, 'The Plea of Illegality in Investment Treaty Arbitration' (2014) 29(1) ICSID Review 155.

62 Other tribunals have treated it as an admissibility bar: see Georg Gavrilovic and Gavrilovic d.o.o. v. Republic of Croatia, ICSID Case No. ARB/12/39, Award, 25 July 2018, paras. 404, 411-415; Copper Mesa Mining Corporation v. Republic of Ecuador, PCA Case No. 2012-02, Award, 15 March 2016, paras. 5.36, 5.62; Bernhard von Pezold and others v. Republic of Zimbabwe, ICSID Case No. ARB/10/15, Award, 28 July 2015, para. 346; Churchill Mining Plc and Planet Mining Pty Ltd v. Republic of Indonesia, ICSID Case No. ARB/12/14 and 12/40, Award, 6 December 2016, para. 528.

63 See e.g. Fraport Ag Frankfurt Airport Services Worldwide v. Republic of the Philippines II, ICSID Case No. ARB/11/12, Award, 10 December 2014, para. 332; Gustav Hamester v. Republic of Ghana, ICSID Case No. ARB/o7/24, Award, 18 June 2010, paras. 123-124; Plama Consortium Limited v. Republic of Bulgaria, ICSID Case No. ARB/o3/24, Award, 27 August 2008, paras. 138-140.

64 Vladislav Kim et al. v. Republic of Uzbekistan, ICSID Case No. ARB/13/6, Decision on Jurisdiction, 8 March 2017, paras. 405-409, 541; Inceysa v. El Salvador (n 61) paras. 208, 224, 237-239; Rumeli Telekom A.s. and Telsim Mobil Telekomikasyon Hizmetleri A.s. v. Republic of Kazakhstan, ICSID Case No. ARB/05/16, Award, 29 July 2008, para. 319; Desert Line v. Yemen (n 61) para. 104.

65 Quiborax S.A et al. v. Plurinational State of Bolivia, ICsid Case No. ARB/o6/2, Decision on Jurisdiction, 27 September 2012, para. 266; Saba Fakes v. Turkey, ICSID Case No. ARB/o7/20, Award, 14 July 2010, para. 119.

66 Cortec Mining Kenya Limited et al. v. Republic of Kenya, ICSID Case No. ARB/15/29, Award, 22 October 2018, para. 9.

67 Ibid., para. 345 . 
Secondly, taking this further, one can envisage an even broader range of DRR obligations in domestic law that could be deemed "fundamental" and enliven an IIA legality clause. A tribunal ruling on this matter could refer to core IDL policy instruments in order to ascertain the kinds of disaster laws that qualify as "fundamental". 68 The Sendai Framework, for instance, identifies national and local laws addressing land use and urban planning, building codes, environmental and resource management and health and safety standards' as warranting particular attention in order to manage disaster risk. ${ }^{69}$ Thus legality for the purposes of an ISDS tribunal's jurisdiction might in future depend on an investor satisfying a set of stringent sub-requirements within development applications, such as 'land degradation assessments' for properties susceptible to coastal erosion or mudslides; ${ }^{70}$ or undertakings to use fire-resistant materials when constructing and operating facilities in fire-prone locations, or to contribute to the upkeep of an adjacent sea wall.

Finally, the fact that Cortec allows a State to invoke national laws relating to disaster prevention and management as a basis for defeating investor claims conduces to a potential synergy between IDL and the international investment law regime. One basic notion in IDL circles is that disaster prevention and response are 'ideally addressed by national and local laws'.71 For its part, the Sendai Framework highlights the need to 'adopt and implement national and local [DRR] strategies and plans'.72 To this end, key IDL instruments are all designed as guiding frameworks to facilitate domestic regulation, including the IF RC's Checklist on Law and Disaster Risk Reduction, ${ }^{73}$ and its Guidelines for the Domestic Facilitation and Regulation of International Disaster Relief and Initial Recovery Assistance. ${ }^{74}$ The legality requirement offers a potential

68 See e.g. United Nations Office for Disaster Risk Reduction, Sendai Framework for Disaster Risk Reduction 2015-203O (18 March 2015) A/CONF.224/CRP.1, adopted by the United Nations General Assembly (UNGA) in Resolution 69/283, (23 June 2015) A/REs/69/283 ("Sendai Framework").

$69 \quad$ Ibid., para. $27(\mathrm{~d})$.

$70 \quad$ Ibid., paras. $3 \mathrm{O}(\mathrm{f}), 33(\mathrm{j})$.

71 Michael Eburn et al., 'Recognising the Limits of International law in Disaster Risk Reduction as Problem and Solution' in Katja L.H. Samuel et al., The Cambridge Handbook of Disaster Risk Reduction and International Law' (CUP 2019) 107, 107.

72 Sendai Framework (n 68) para. 27(b).

73 IFRC, Checklist on Law and Disaster Risk Reduction: An Annotated Outline (IFRC, 2015) <https://www.ifrc.org/Global/Publications/IDRL/Publications/The\%2oChecklist\%2O on\%2olaw\%2oand\%2oDRR\%2oOct2015\%2oEN\%2ov4.pdf>.

74 IFRC, Introduction to the Guidelines for the Domestic Facilitation and Regulation of International Disaster Relief and Initial Recovery Assistance (IFRC, 2011) <https://www .ifrc.org/PageFiles/41203/12056oo-IDRL\%2OGuidelines-EN-LR\%2o(2).pdf>. 
means of operationalising the ISDS framework to the advantage of IDL and its objectives. Treating national DRR laws as a precondition to holding a protected investment under IIAs may encourage States to enact, and foreign investors to comply with, such laws.

\subsection{Substantive Entry Points}

Disasters have also impacted aspects of the merits of ISDS proceedings, both upon an investor's claims and a respondent State's pleadings in defence or mitigation. Each is considered in turn.

\subsubsection{Raised by the Investor}

Disasters or the corresponding responses by States can form part of the factual and regulatory matrix on which an investment claim may be based. Five ISDS proceedings demonstrate this.

First, in Ballantine v. Dominican Republic, ${ }^{75}$ the Claimants had purchased properties in mountainous areas of the Dominican Republic in the early 2000 s with a view to creating a luxury area for mountain homes. In 2009, however, the Republic's government created a national park and 32 new protected areas as part of a 'nationwide environmental protection initiative', ${ }^{76}$ which captured some of the Claimants' properties. According to evidence tendered by the Respondent, the national park was especially significant in ecological terms 'for the preservation of ecosystemic services, especially in relation to the production and protection of water in order to avoid potential landslides, given the intense annual dry and rainy seasons.' ${ }^{77}$ Nonetheless, the Claimants argued that the decree creating the national park, as well as a subsequent decision rejecting their application for an expansion permit for their development, violated the "fair and equitable treatment" (FET) standard in the DR-CAFTA. ${ }^{78}$ The Tribunal found it lacked jurisdiction over the dispute, however, meaning the intriguing possibilities of how a measure enacted pursuant to DRR objectives might be treated within the FET rubric were left unaddressed.

Secondly, the proceedings in Vattenfall $\nu$. Germany (II) concerned the German government's measures accelerating a country-wide phase-out of nuclear power plants. ${ }^{79}$ These measures were implemented amidst public out-

\footnotetext{
75 Michael Ballantine and Lisa Ballantine v. Dominican Republic, PCA Case No. 2016-17, Award, 3 September 2019 .

$76 \quad$ Ibid., para. 64 .

77 Ibid., para. 65 (emphasis added).

78 Ibid., para. 341 .

79 Vattenfall v. Germany (II) (n 15).
} 
cry over the 2011 Fukushima nuclear disaster in Japan. ${ }^{80}$ The Claimants sought $€_{4.7}$ billion in compensation, alleging that the measures amount to expropriation and a violation of their legitimate expectations under the Energy Charter Treaty (ECT). ${ }^{81}$ In parallel proceedings before the Federal Constitutional Court of Germany, two judgments of December 2016 and September 2020 both held that the legislation implementing the accelerated timeframe for decommissioning was invalid under domestic law. ${ }^{82}$ Eventually, and no doubt concerned by the potential impact of these adverse rulings on any award in the ECT proceedings, Germany reached a settlement of $€ 2.4$ billion with the Claimants in March 2021. ${ }^{83}$ The initiation, ten-year stalemate and settlement of these arbitral proceedings - all at significant financial and reputational cost to Germany - signifies the risk of DRR measures being challenged through ISDS mechanisms. It also looms as a vital yardstick for the prospects of pending and future claims challenging State initiatives to accelerate the decommissioning of coal-fired power plants. ${ }^{84}$

Thirdly, in Hydro S.R.L. v. Albania, ${ }^{85}$ a series of 18 floods, in addition to 'heavy rainfall and inclement weather, including landslides', ${ }^{86}$ delayed the Claimants' performance of a contract for the construction of a hydroelectric power plant in Kalivaç in southern Albania. An aspect of the Claimants' FET claim was that Albania had undermined their legitimate expectations by 'failing to engage with the Claimants regarding floods adversely affecting the [p]roject'.87 They argued that the delays to the project (to which Albania had contributed through inadequate post-disaster assistance) resulted in the project missing the deadline for eligibility to participate in green energy incentive

8o Lars Kramm, 'The German Nuclear Phase-Out After Fukushima: A Peculiar Path or an Example for Others?' (2012) 3(4) Renewable Energy Law and Policy Review 251.

81 Nathalie Bernasconi-Osterwalder and Rhea Tamara Hoffmann, 'The German Nuclear Phase-Out Put to the Test in International Investment Arbitration? Background to the new dispute Vattenfall v. Germany (II)' (IISD, 5 June 2012) < https://www.iisd.org/system/ files/publications/german_nuclear_phase_out.pdf>.

82 Daniela Páez-Salgado, 'A battle on Two Fronts: Vattenfall v. Federal Republic of Germany' (Kluwer Arbitration Blog, 18 February 2021) <http://arbitrationblog.kluwerarbitration .com/2021/o2/18/a-battle-on-two-fronts-vattenfall-v-federal-republic-of-germany/>.

83 Cosmo Sanderson, 'Germany settles with Vattenfall' (Global Arbitration Review, 5 March 2021) <https://globalarbitrationreview.com/germany-agrees-settle-vattenfall-case>.

84 See e.g. Westmoreland Coal Company v. Government of Canada, ICSID Case No. UNCT/ 20/3; RWE AG and RWE Eemshaven Holding II BV v. Kingdom of the Netherlands, ICSID Case No. ARB $/ 21 / 4$.

85 Hydro S.R.L. et al. v. Republic of Albania, ICSID Case No. ARB/15/28, Award, 24 April 2019.

86 Ibid., paras. 247-248.

$87 \quad$ Ibid., para. 631(b). 
scheme, from which it had reasonably expected to benefit. ${ }^{88}$ The tribunal rejected this head of claim for want of causation: none of Albania's impugned conduct (including its alleged lack of post-disaster support) contributed to the true reason for the delays, which was a lack of finance. ${ }^{89}$ Nonetheless, this demonstrates the potential for a State's disaster response measures to be challenged by reference to the FET standard.

Fourthly, in Petrobart $v$. Kyrgyzstan, ${ }^{90}$ the proceedings concerned a gas supply contract between the Claimant and the Respondent's state-owned gas company KGM. ${ }^{91}$ After KGM failed to make contractually required payments, the Claimant obtained judgment in its favour in the Kyrgyz courts. However, execution of this judgment was stayed, allegedly on the request of the Kyrgyz Vice Prime Minister, and the Claimant initiated proceedings. Relevantly, KGM explained its inability to pay as the result of having 'taken measures to give assistance to the inhabitants of the Suzakski region who were suffering from the consequences of a natural disaster'.92 This demonstrates the propensity for a State organ or instrumentality's involvement in disaster recovery to leave it vulnerable to defaulting on obligations to foreign investors, and to thereby attract investment claims down the line.

Finally, in Chevron and Texaco v. Ecuador (II), the Claimants challenged an Ecuadorian court's 2011 judgment which had found them liable to the sum of US $\$ 9.5$ billion for the egregious environmental damage and public health impacts caused by their oil extraction operations at the Lago Agrio oil field between 1964 and 1992. ${ }^{93}$ The Claimants alleged that the Ecuadorian judicial proceedings were tainted by misconduct - particularly, through corrupt collusion which saw the plaintiffs bribe the judge and "ghostwrite" the judgment on his behalf. Among their claims, they argued that these facts amounted to a denial of justice in violation of the FET standard in the US-Ecuador Bilateral Investment Treaty (BIT). In a partial award of 3 O September 2018, an UNCITRAL tribunal accepted this head of claim, finding that the judge's conduct was

$88 \quad$ Ibid., para. 634 .

$89 \quad$ Ibid., paras. $643^{-653}$.

90 Petrobart Limited v. Kyrgyz Republic, scc Case No. No. 126/2003, Arbitral Award, 29 March 2005.

91 The tribunal did not expressly address whether KGM was vested with governmental authority under the ILC rules of attribution, but hinted at its governmental nature when noting that it had been 'created for the purpose of rationalization of the use of the stateowned infrastructure for oil, as well as natural and liquid gas product supply': ibid., 4 .

92 Ibid., 5 .

93 Chevron Corporation and Texaco Petroleum Corporation v. Ecuador (II), PCA Case No. 2009-23. 
'grossly improper by any moral, professional and legal standards'. ${ }^{94}$ While leaving open the possibility for individual victims to bring domestic claims against the Claimants for personal harm, ${ }^{95}$ it ordered Ecuador to 'take immediate steps, of its own choosing, to remove the status of enforceability from the Lago Agrio Judgment. ${ }^{96}$ This finding has since been upheld by the District Court of The Hague, with a (likely substantial) award to follow.

This dispute has been a focal point for those highlighting the incompatibility of environmental protection objectives with the investment arbitration framework. ${ }^{97}$ It also demonstrates that domestic measures (in this case, judicial proceedings) designed to hold foreign investors responsible for their contribution to a disaster remain liable to challenge under IIAs - even on grounds entirely unrelated to the need, effectiveness or moral significance of the measure as a component of the State's disaster response. This confirms the obvious proposition that the IDL perspective is by no means peremptory or overriding in a State's policy calculus. Disaster policies require not only a delicate balancing of interests at the design stage, but also a longer-term strategy for consistent and lawful implementation across State organs.

These scenarios demonstrate how disasters complicate the facts underpinning an investor's relationship with its host State, and thus are potentially generative of investment claims. All manner of disaster prevention, recovery and response measures may be challenged for affecting the profitability of an investment. These span from measures with directly adverse effects in their own right (e.g. land rezoning in Ballantine or a nuclear phase-out in Vattenfall), to measures which incidentally create a regulatory context for potential IIA violations to occur (e.g. domestic judicial proceedings to assess an investor's liability for an environmental disaster in Chevron, or decisions on post-disaster resource allocation in Petrobart).

\subsubsection{Raised by the State \\ 2.3.2.1 NPM Clauses}

A State's disaster policy measures, if challenged by an investor, may also implicate "non-precluded measures" (NPM) clauses, which operate by excluding governmental measures enacted in aid of an enumerated list of public objectives from the scope of an IIA's substantive protections, where expressly

94 Ibid., Second Partial Award on Track II, 30 August 2018, para. 8.59.

95 Ibid., para. 7.37.

96 Ibid., para. 10.13(i).

97 Lorenzo Pellegrini et. al., 'International Investment Agreements, Human Rights, and Environmental Justice: The Texaco/Chevron Case from the Ecuadorian Amazon' (2020) 23/2 Journal of International Economic Law 455 . 
provided therein. ${ }^{98}$ One State so far has unsuccessfully sought to invoke disaster management to this end.

In Deutsche Telekom v. India ${ }^{99}$ and Devas v. India, ${ }^{100}$ both proceedings concerned the Indian government's 2011 decision to cancel an agreement for the lease of two satellites. A key question was whether cancellation served to protect an 'essential security interest' of the Respondent within the meaning of the NPM clauses in the Germany-India BIT and India-Mauritius BIт. The clauses were differently worded, the former requiring the measure to be 'necessary' to protect such an interest, the latter merely requiring it to be 'directed at' the protection thereof. By invoking the clause, India sought to defeat the investor's claim for want of jurisdiction.

Accordingly, India explained that the decision was taken for national security reasons, in order to preserve the S-band spectrum in which the satellites operated for military activities, but also for the needs of 'railways and other public utility services as well as for societal needs, and having regard to the needs of the country's strategic requirements.'101 Among these 'societal needs', India cited the provision of services for 'disaster management', 'emergency

98 An earlier variety of an NPM clause was art. $\mathrm{x}$ of the US-Panama BIT (1982), which stipulates: 'This treaty shall not preclude the application by either Party of any and all measures necessary for the maintenance of public order, the fulfilment of its obligations with respect to the maintenance or restoration of international peace and security, or the protection of its own essential security interests. A more recent and extensive clause in art. 15(1) of the Australia-Uruguay BIт (2019) reads: 'Subject to the requirement that such measures are not applied by a Party in a manner which would constitute arbitrary or unjustifiable discrimination between investments or between investors, or a disguised restriction on international investment, nothing in this Agreement shall be construed so as to prevent a Party from adopting or enforcing measures: (a) necessary to protect human, animal or plant life or health; (b) necessary to protect public morals or to maintain public order; (c) necessary to secure compliance with laws or regulations which are not inconsistent with the provisions of this Agreement; (d) imposed for the protection of national treasures of artistic, historic or archaeological value; or (e) relating to the conservation of living or non-living exhaustible natural resources.' For an explanation of how NPM clauses operate in investment arbitration, see Caroline Henckels, 'Scope Limitation or Affirmative Defence? The Purpose and Role of Investment Treaty Exception Clauses' in Lorand Bartels and Federica Paddeu (eds), Exceptions in International Law (oup 2020) 363 .

99 Deutsche Telekom v. India, PCA Case No. 2014-10, Interim Award, 13 December 2017 ("Deutsche Telekom").

100 Cc/Devas (Mauritius) Ltd., Devas Employees Mauritius Private Limited and Telecom Devas Mauritius Limited v. India, PCA Case No. 2013-09, Award on Jurisdiction and Merits, 25 July 2016 ("Devas").

101 Ibid., para. 5, citing Press Information Bureau of the Government of India, 'CCS Decides to Annul Antrix-Devas Deal', 17 February 2011. 
communication' and 'dissemination of disaster warnings'.102 However, the tribunal in Devas cursorily rejected the latter argument, averring that these 'societal needs' covered a 'wide range of government activities which clearly [had] no relationship with the essential security interests of the State.103 The tribunal in Deutsche Telekom reached the same conclusion on this point, holding:

[The Tribunal] cannot see how, on any reasonable reading of Article 12, other "societal needs", such as train-tracking, disaster management, teleeducation, tele-health and rural communication, appearing side by side with the strategic interests in numerous documents, could be included within the "essential security interests" without distorting the natural meaning of such term. ${ }^{104}$

The tribunals ultimately diverged on their conclusions, with the Devas tribunal finding that the relevant NPM clause had been partially engaged in respect of the spectrum reserved for national security purposes, ${ }^{105}$ and the Deutsche Telekom tribunal finding that its more stringently phrased NPM clause had not been satisfied at all. ${ }^{106}$ Nonetheless, on the view of both tribunals, DRR measures would not appear to fall within the ambit of carve-out clauses protecting 'essential security interests'. But this view is out of kilter with the basic IDL proposition that disasters pose a 'major threat to human security',107 and so future ISDS tribunals may reach a different conclusion on this basis.

\subsubsection{Counterclaims}

States may also bring counterclaims to seek remedy for an investor's contribution to or exacerbation of the impacts of a disaster. Typically, the preconditions for bringing a counterclaim have been that (1) the parties have consented to arbitrate counterclaims, and (2) that it bears sufficient connection to the underlying claim. ${ }^{108}$ These conditions were clarified in Urbaser v. Argentina, in which an ICSID tribunal took jurisdiction over, but ultimately rejected,

\footnotetext{
102 Deutsche Telekom (n 99) para. 26o; Devas (n 10o) para. 36o.

103 Devas (n 100) para. 36o (emphasis added).

104 Deutsche Telekom (n 99) para. 281.

105 Devas (n 100) para. 371.

106 Deutsche Telekom (n 99) para. 288.

107 Arnold N. Pronto, 'International Disaster Law' in Robin Geiß and Nils Melzer (eds), The Oxford Handbook of the International Law of Global Security (oup 2021) 566, 567 .

108 See ICSID Convention (n 21) art. 46; see also Iberdrola Energia S.A. v. Republic of Guatemala II, PCA Case No. 2017-41, Final Award, 24 August 2020, para. 384 .
} 
a counterclaim based on an investor's alleged violation of a positive obligation to ensure the Argentine population's human right to water. ${ }^{109}$ Recently, States have made successful counterclaims to remedy environmental damage caused by investors. ${ }^{110}$ This first occurred in Perenco v. Ecuador and Burlington v. Ecuador, in which tribunals ordered the respective investors to compensate the State for damage that their oil extraction operations caused to the 'environmentally fragile areas in the Amazon rainforest' in which they operated. ${ }^{111}$ Subsequently, in Aven. v. Costa Rica, the tribunal accepted it had prima facie jurisdiction under a BIT over a counterclaim alleging a violation of Costa Rican environmental laws. ${ }^{112}$ It held:

[I] t can no longer be admitted that investors operating internationally are immune from becoming subjects of international law. It is particularly convincing when it comes to rights and obligations that are the concern of all States, as it happens in the protection of the environment. ${ }^{113}$

Extending this reasoning, DRR is gradually being recognised as a 'concern of all States', as the causal link between anthropogenic climate change and disasters becomes ever clearer. ${ }^{114}$ Accordingly, counterclaims could potentially lie one day, subject to the establishment of jurisdiction and sufficient connection, in respect of an investor's failure to implement practices or policies to "disasterproof" its investment, where this failure results in excessive damage to the environment or human communities during a disaster.

109 Urbaser SA and Consorcio de Aguas Bilbao Bizkaia, Bilbao Biskaia Ur Partzuergoa v. The Argentine Republic, ICSID Case No ARB/o7/26, Award, 8 December 2016, paras. 1143-1155 (identifying and assessing the jurisdictional requirements of the counterclaim), 1182-1221 (assessing and rejecting the counterclaim on the merits).

110 See generally Anna Bilanova, 'Environmental Counterclaims in Investment Arbitration' (2020) 5 European Investment Law and Arbitration Review, 400.

111 See Perenco Ecuador Ltd. v. Republic of Ecuador and Empresa Estatal Petróleos del Ecuador (Petroecuador), ICSID Case No. ARB/o8/6, Interim Decision on the Environmental Counterclaim, 11 August 2015, para. 37; Burlington Resources v. Republic of Ecuador, ICSID Case No. ARB/o8/5, Decision on Counterclaims, 7 February 2017.

112 David Aven et. al. v. The Republic of Costa Rica, UnCitral Case No. UnCt/15/3, Award, 18 September 2018, paras. 732-740. See generally Debadatta Bose, 'David R Aven v Costa Rica: The Confluence of Corporations, Public International Law and International Investment Law' (2020) 35/1-2 ICSID Review, 20.

113 Ibid., para. 738.

114 Sendai Framework (n 68) para. 19(a). 


\subsubsection{Defending Substantive Claims}

A State may also invoke a disaster as a fact germane to its defence against a substantive claim. There are four decisions which demonstrate this, each involving the FET standard.

First, the dispute in Crystallex $v$. Venezuela partly concerned the Venezuelan government's decision to deny the Claimants' application for a permit to exploit deposits in the Las Cristinas goldmine. ${ }^{115}$ Among its claims, the Claimants alleged a violation of the FET standard under the Canada-Venezuela BIT, arguing that the decision was procedurally defective and undermined its legitimate expectations. ${ }^{116}$

Venezuela stressed from the outset that 'the geography and topography of the Las Cristinas area present[ed] particular challenges to its development', including 'its location in a remote tropical rainforest, affected by heavy rainfall and seasonal flooding. ${ }^{117}$ In the course of deciding the permit application, the Venezuelan Ministry of Environment had sought clarification from the Claimants as to 'whether the water diversion channel [proposed by the Claimants for the mine] would be designed to withstand a 20o-year flood of all our streams whose water it was designed to carry'.118 Venezuela contended that it was 'prudent and reasonable' to deny the permit because, among other shortcomings, the Claimants' application 'did not identify a post-construction floodplain or address the potential flood risks in and around the proposed mine facilities.'119

The tribunal ultimately found a violation of the FET standard in both its 'legitimate expectations' and 'arbitrary and inconsistent treatment' modalities. The former conclusion turned on a letter that the Ministry had issued one year before denying the permit, in which it claimed to have 'analysed and approved' the Claimants' environmental impact statement. ${ }^{120}$ The tribunal held that this letter 'created a legitimate expectation in Crystallex that the procedure of the permitting process would go ahead for the exploitation of gold relating to the entire Las Cristinas project', which was undermined when the Ministry denied the permit. ${ }^{121}$

Moreover, it held that the decision was arbitrary and lacked transparency and consistency. While Venezuela had the right (and the responsibility) to

\footnotetext{
115 Crystallex v. Venezuela (n 49) para. 6.

116 Ibid., para. 485 .

117 Ibid., para. 204.

118 Ibid., para. 228.

119 Ibid., paras. $383-384$.

120 Ibid., para. 252.

121 Ibid., para. 575 .
} 
raise concerns relating to global warming, environmental issues, [...] biodiversity, and other related issues, ${ }^{\prime 22}$ the tribunal took umbrage with the way that these concerns had been raised in the denial letter. Among other things, it observed that the issue of global warming had not once been raised in the 'innumerable occasions of exchanges' during the 4-year review process leading up to the letter; ${ }^{123}$ and that concerns about an 'alteration of hydrology' were invoked 'in vague terms and without any supporting authority'. ${ }^{124}$ The inconsistency became more marked after the denial letter, through a series of Ministry and presidential press releases celebrating the financial benefits of the decision and eliding any reference to environmental concerns. ${ }^{125}$

The tribunal did not expressly address whether it was valid for the Ministry to incorporate DRR policy considerations (i.e. floodplain management) into its permit approval process, though its oblique and open-ended references to 'other related issues' and 'alteration of hydrology' hint that it was. However, the outcome indicates that States wishing to factor DRR considerations into EIA procedures may be required to comply with rather exacting standards of transparency and consistency when doing so.

Secondly, in Teinver v. Argentina, the Claimant alleged that governmental measures relating to the air transport sector (including announcement of Decree 1012/2016, which proposed cuts to VAT for fuel, $20 \%$ increases to airfares and a fuel subsidy for domestic air transportation) undermined its legitimate expectation that it would be entitled to charge 'economically reasonable airfares', both due to their inadequacy and delay in implementation. ${ }^{126}$ One of Argentina's justifications for the decree was that it accounted for the consequences of hurricanes Katrina and Wilma on the price of aviation fuel. ${ }^{127}$ The Tribunal found, on this point, that the 'alleged delay and inadequacy in the airfare increase granted in Decree 1012/2006 in August 2006 [could not] give rise to a breach of the [FET standard]'.128

The tribunal's rejection of the legitimate expectations component of the FET claim was pertinent. Alongside the impacts of Hurricanes Katrina and Wilma, it noted the 'serious financial difficulties' of the airline industry post-20o1 and the parlous state of the Argentine economy as factors that the investors should

\footnotetext{
122 Ibid., para. 591.

123 Ibid., paras. 592, 598.

124 Ibid., para. 592.

125 Ibid., paras. 602-605.

126 Teinver S.A., Transportes de Cercanías S.A. and Autobuses Urbanos del Sur S.A. v. Argentine Republic, ICSID Case No. ARB/og/o1, Award, 21 July 2017, paras. 655, 737.

127 Ibid., para. 408.

128 Ibid., para. 746.
} 
have been aware of at the time of investing. ${ }^{129}$ While the tribunal found a violation of the FET standard on other grounds, ${ }^{130}$ its reasoning is significant, as it opens the door for States to rebut legitimate expectations claims in a similar manner in a disaster-heightened future world. For instance, an investor's expectations about regulatory stability may not be reasonable if the State's economy has recently been ravaged by a disaster - even a disaster overseas with global economic repercussions. More generally, States may also argue that an investor should have exercised due diligence to ascertain whether it would be operating in a disaster-prone industry (e.g. airlines vulnerable to travel restrictions or caps during a pandemic); or whether its investment would be susceptible to disaster response-based regulatory changes (e.g. a state-wide lockdown, or a ban on non-fire-resistant materials, or a requisition of coastal properties threatened by sea-level rises).

Thirdly, in Allard v. Barbados, ${ }^{131}$ the Claimant alleged that the Respondent had caused the environmental degradation of his investment, an ecotourism "sanctuary" which spanned 34 acres of wetlands on the south coast of Barbados. He argued that governmental conduct, including a sewage spill, zoning changes, and mismanagement of the sluice gate which regulated water flow between his wetlands and the ocean, had caused declines in the water salinity, water quality and biodiversity of his sanctuary. ${ }^{132}$ On this basis, he alleged violations of the FET, full protection and security (FPS), and expropriation standards in the Canada-Barbados Biт.

In order to dispute causation, the Respondent made various arguments to the effect that disasters and other natural events had caused the degradation of the sanctuary.133 First, it submitted that the ecology of the site had been under 'pre-existing physical constraints.' ${ }^{134}$ It explained that a tropical storm from 1984 had resulted in an accretion of sand between the sluice gate and the sea, which 'limited the interchange of water between [them]', ${ }^{135}$ and meant that subsequent management of the gate could not have had a significant impact on water salinity. ${ }^{136}$ The Tribunal agreed with this point: the Claimant had not shown that 'the passage of seawater through the [gate] was a significant component in maintaining the salinity of the Sanctuary lake, such that the

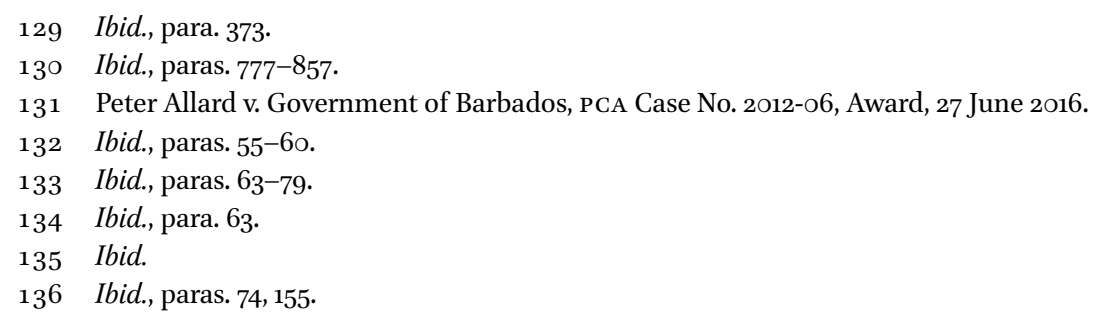


irregular and infrequent operation of the [gate] would cause a non-negligible decrease in salinity' ${ }^{\prime} 37$

Secondly, it argued that the Claimant's measurements which evidenced a decline in salinity were misleading. It argued that one low reading in February 2010 resulted from the Claimant's practice of pumping freshwater into the sanctuary's swamp in order to maintain water levels during periods of drought. ${ }^{138}$ The Respondent's expert explained another low reading as being caused by a 'significant storm event'. ${ }^{139}$ On this point, the Tribunal sided with the Claimant. While accepting that there was 'seasonal variation in the salinity of the [s]anctuary waters', ${ }^{140}$ it dismissed the Respondent's expert's reliance on the storm event as 'speculative and inconsistent' with other reports. ${ }^{141}$ Those reports, viewed together, demonstrated a decline in salinity beyond that which the Claimant could have induced itself. ${ }^{142}$

The Tribunal eventually concluded that there had been no degradation of the environment, and that even if there had been, it was not caused by any actions or inactions of the Respondent. ${ }^{143}$ It proceeded to reject the Claimant's FET claim, ${ }^{144}$ FPS claim, ${ }^{145}$ and expropriation claim. ${ }^{146}$ Accordingly, these proceedings demonstrate the potential for a respondent State, when defending a substantive claim, to argue that a disaster has broken the chain of causation between its actions and any damage suffered by the investor.

Finally, in Methanex Corporation $v$ United States of America, ${ }^{147}$ the US argued that it had decided to prohibit the gasoline additive мTвE partly upon the recommendations of a scientific report which detailed, inter alia, that the use of the additive would exacerbate the severity of water shortages during drought years. ${ }^{148}$ The UNCITRAL tribunal, finding the report to reflect a 'serious, objective and scientific approach to a complex problem in California' and 'accept[ing] without reservation these experts' conclusions',149 ultimately concluded that the prohibition was 'made for a public purpose, was

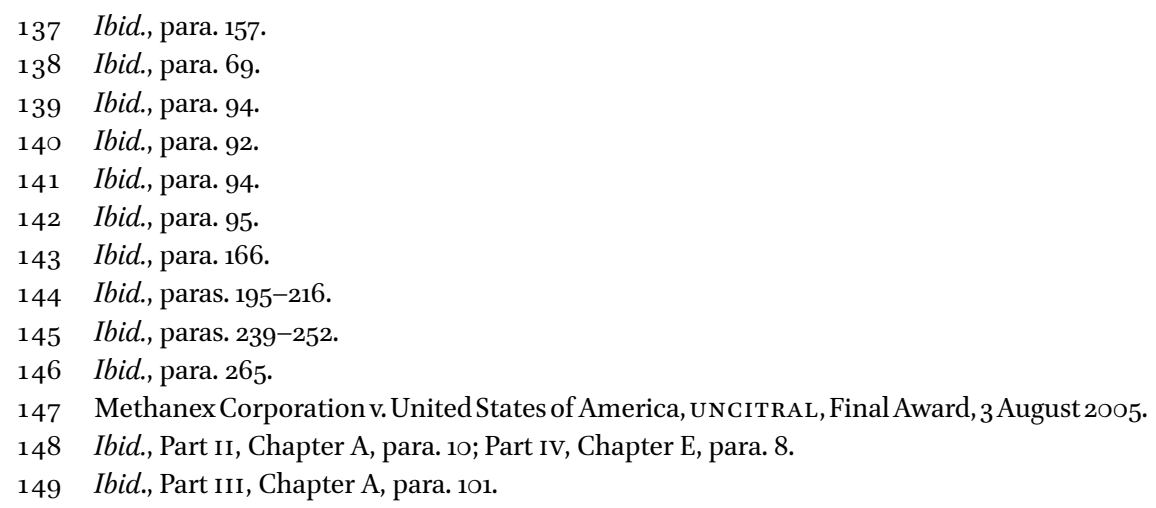


non-discriminatory and was accomplished with due process'.150 It thus did not violate the national treatment, FET or expropriation standards in NAFTA Articles 1102, 1105 or 1110.

This illustrates that governmental decisions made pursuant to credible scientific evidence about disaster risks may not be liable under IIAs as they fall into the realm of legitimate regulation in the public interest. In future, this line of argument may assist a State to rely on the "police powers" doctrine under customary international law (as a carve-out to expropriation); justify discrimination under the national treatment and MFN standards; or, for FET purposes, to negate a finding of substantively "arbitrary" or "unreasonable" treatment, or to undercut the "reasonableness" of an investor's expectations. Again, core IDL instruments such as the Sendai Framework would assist any State invoking these public interest-based carve-outs, as evidence of the widespread belief that DRR is a 'common concern' for all States which requires the 'full engagement of all State institutions of an executive and legislative nature at national and local levels.' ${ }^{151}$ This represents another point of potential synergy between IDL and investment law: as disaster regulation comes to recognised as a potential basis on which States can defend investment claims, it may encourage (or, at least, remove one obstacle to) the enactment of more robust disaster regulation, and thereby advance the objectives of IDL.

\subsubsection{Damages and Mitigation}

Finally, three cases have addressed the implications of disasters at the stage of quantum assessment. In Railroad Development Corporation v. Guatemala, ${ }^{152}$ the Claimant sought to recover lost revenues from a transloading operation affected when Hurricane Stan, a cyclone of October 2005 that triggered torrential rainfall, mudslides and floods and killed 1668 people across Central America, disrupted the railroad connecting two Guatemalan transit points. The tribunal refused to include these revenues in its assessment of damages, in part because the disruption had occurred 'through no fault of Guatemala'.153 Thus disasters may be a supervening event which breaks the chain of causation and renders a claimant's alleged losses non-recoverable.

\footnotetext{
$15 \mathrm{O}$ Ibid., Part IV, Chapter D, para. 15.

151 Sendai Framework (n 68) paras. 19(a), 19(e).

$15^{2}$ Railroad Development Corporation v. Republic of Guatemala, ICSID Case No. ARB/o7/23, Award, 29 June 2012.

153 Ibid., para. 276.
} 
Secondly, in Cargill v. Mexico, ${ }^{154}$ damage to US sugar production caused by Hurricane Katrina had prompted the United States and Mexico to negotiate temporary and exceptional trade arrangements, under which the Claimant received $34 \%$ of the total quota of high-fructose corn syrup allowed into Mexico between 2005 and 2008. The Tribunal treated this amount as 'mitigation to Claimant's damages claim.'155

Finally, in Grenada Private Power v. Grenada, ${ }^{156}$ the question arose whether self-insurance against hurricane damage taken out by the Claimants for their electricity supply company should be treated as an equity reserve or liability for the purposes of quantum assessment. ${ }^{157}$ The Tribunal sided with the Respondent, ${ }^{158}$ and treated the contributions as liabilities when determining the appropriate quantum of compensation. ${ }^{159}$

\section{$2.4 \quad$ Enforcement}

Finally, disasters have informed the decisions of (at least) six ICSID annulment committees and domestic courts as to whether to grant a stay of enforcement.

First, in the annulment proceedings in Burlington Resources v. Ecuador, ${ }^{160}$ Ecuador cited the 'economic consequences' of an April 2016 earthquake in north-western Ecuador - a 7.8 magnitude earthquake that 'killed more than 650 people and injured more than $16,600^{\prime 161}$ - as a "hardship" which justified the continuation of a stay of enforcement under Article 52(5) of the ICSID Convention. ${ }^{162}$ The ad hoc Committee rejected the argument, finding that the facts adduced by Ecuador were not of the requisite severity to meet the threshold for "hardship" adopted in other cases on which Ecuador had relied (that being 'catastrophic, immediate and irreversible' consequences if the stay were lifted $\left.{ }^{163}\right) \cdot{ }^{164}$ It concluded that ' $[\mathrm{t}]$ he consequences described by Ecuador do not match the scarcity of foreign exchange in Guinea in the

154 Cargill, Incorporated v. United Mexican States, ICSID Case No. ARB(AF)/05/2, Award, 18 September 2009, paras. 527-533.

155 Ibid., para. 533 .

156 Grenada Private Power Limited and wrb Enterprises, Inc v. Grenada, ICsid Case No. ARB $/ 17 / 3$, Award, 19 March 2020.

157 Ibid., para. 286.

158 Ibid., para. 290.

159 Ibid., para. 323 .

16o Burlington Resources, Inc. v. Republic of Ecuador, ICSID Case No. ARB/o8/5, Decision on Stay of Enforcement of the Award, 31 August 2017.

161 Ibid., para. 80.

162 Ibid., paras. 21, 80.

163 Ibid., para. 79 .

164 Ibid., para. 81 . 
case of MINE or the instability in DRC, a country ravaged by war, in the case of Mitchell'.165 In coming years, however, as the economic and migratory impacts of disasters become more 'catastrophic' in warmed climatic conditions, many disasters may satisfy this threshold.

Secondly, in the annulment proceedings in Tethyan Copper v. Pakistan, ${ }^{166}$ Pakistan sought the continuation of a stay of enforcement, partly on grounds that payment of the \$US 5.8 billion award would have 'disastrous effects on the State's capacity to meet public needs, including the loss of life and the impact on programs designed to face the crisis of the CoviD-19 pandemic.'167 It argued that Article 52(5) of the ICSID Convention, which established the tribunal's discretion to grant a stay, should be interpreted by reference to international legal instruments establishing the rights to life and health. ${ }^{168}$ It considered that immediate enforcement would 'hinder Pakistan's performance of [these] obligation[s].'169

Conversely, the Claimants argued that Pakistan had not explained how enforcement would 'compromise its current or near-term efforts to respond to the pandemic', especially as it would not entail immediate payment. ${ }^{170}$ The Committee ultimately accepted the latter argument regarding the pandemic (though ultimately granting a conditional stay on other grounds). After observing that Article 52(5) does not mandate consideration of any fixed criteria, ${ }^{171}$ it found that lifting the stay would not affect Pakistan's ability to 'respond promptly and effectively to a pandemic', nor to comply with human rights obligations. ${ }^{172}$ It reasoned:

[W]hile the Committee recognizes the potential hardship that Pakistan may suffer due to a lifting of the stay, it is not convinced of the likelihood that Pakistan would suffer the severe hardship on an immediate basis to the degree it claims. Enforcement would be delayed, and payment of the entire Award would not be immediate. ${ }^{173}$

\footnotetext{
165 Ibid., para. 81.

166 Tethyan Copper Company Pty Limited v. Islamic Republic of Pakistan, ICsid Case No. ARB $/ 12 / 1$, Decision on Stay of Enforcement of the Award, 17 September 2020.

167 Ibid., para. 64 .

168 Ibid., para. 43 (citing ICCPR art. 6(1) and wHo International Health Regulations 2005 art. 13(1)).

169 Ibid.

170 Ibid., para. 8o.

171 Ibid., para. 128.

172 Ibid., para. 156.

173 Ibid., para. 157 (emphasis added).
} 
Thirdly, a publicly available instance in which a stay has been granted directly on COVID-19 grounds is in Union Fenosa Gas v. Egypt. In those proceedings, a US court stayed enforcement of a \$US 2 billion award until an ICSID committee had ruled on annulment because (among other things) Egypt was facing a 'massive fiscal crisis exacerbated by the ongoing Covid-19 pandemic', and the court was 'loath to plunge so deeply into a sovereign's treasury during a period of immense uncertainty if there is a chance that the award might be set aside or mitigated to some extent'. ${ }^{\prime 74}$

Fourthly, in US enforcement proceedings in Yukos v. Russian Federation, ${ }^{175}$ the Respondent sought a stay partly on the basis that the CoviD-19 pandemic had raised 'uncertainties' weighing in favour of a stay. ${ }^{176}$ In this regard, it cited the earlier decision in Union Fenosa. However, the Court opined that while the pandemic has 'certainly created unprecedented uncertainty for the economies of some countries and their administrative operations across the world', the circumstances were distinguishable from those facing Egypt in Union Fenosa. While Egypt was facing a 'massive fiscal crisis exacerbated by the [pandemic], recent Russian activities (namely, filings in the Dutch Supreme Court as well as unspecified 'development and cultural activities' in Russia) suggested it faced no similar crisis. In the absence of clearer evidence of fiscal hardship, it rejected this ground. ${ }^{177}$

The pandemic was also invoked in the ConocoPhillips v. Venezuela annulment proceedings as a hardship exacerbating Venezuela's economic crisis and justifying continuation of a stay. ${ }^{178}$ The ad hoc Committee rejected this argument 'absent a demonstration that the worldwide sanitary crisis has worsened the perspectives of payment of the Award, ${ }^{\prime 179}$ and the stay was discontinued. A US court also summarily refused a stay on COVID-19 grounds in TECO $v$. Guatemala. 180

174 Unión Fenosa Gas, S.A. v. Arab Republic of Egypt, ICSID Case No. ARB/14/4, Memorandum Opinion of US District Court for the District of Columbia, 4June 2020, para. 18.

175 Yukos Universal Limited (Isle of Man) v. Russia, PCA Case No. 2005-04/AA227, Memorandum Opinion of US District Court for the District of Columbia IV, 20 November 2020.

176 Ibid., para. 3 o.

177 Ibid.

178 ConocoPhillips Petrozuata B.v., ConocoPhillips Hamaca B.v. and ConocoPhillips Gulf of Paria B.V.v. Bolivarian Republic of Venezuela, ICSID Case No. ARB/o7/3o, Decision on the Request to Continue the Stay of Enforcement of the Award, 2 November 2020, para. 26.

179 Ibid., para. $5^{2}$.

18 o TECO Guatemala Holdings, LLC v. Republic of Guatemala, ICSID Case No. ARB/10/23, Order of the United States Court of Appeals for the District of Columbia Circuit, 21 May 2020. 
Considering the above case law, one can draw three propositions about the past and future interfaces between investment arbitration and disasters.

First, while IDL has exerted limited influence on the investment arbitration system up to now, with only a few dozen proceedings over three decades of treaty-based arbitration involving disasters in any capacity, this will most certainly change. As climate scientists forecast, disasters will increasingly pervade and disrupt every facet of human existence, and the investment arbitration framework will not be immune to these disruptions. The recent wave of COVID-19-affected proceedings is a harbinger for this upsurge.

Secondly, disasters have so far more commonly generated discrete questions of procedure than affected substantive claims. Most often, they have prompted parties to request the modification of procedural schedules, or States to seek protections relating to costs and enforcement, where the economic strain of a disaster and/or disaster response temporarily impedes their ability to meet financial obligations in arbitration. But in future, disasters will have both systemic and jurisprudential significance on investment arbitration.

Systemically, disasters will form the context of new swathes of investment claims. On the one hand, more extensive DRR, response and recovery measures taken by States will affect disaster-unrelated investments. These measures may range from macroeconomic policies, stringent zoning and land use plans, and restrictions on commerce and human movement, to hazard reduction burns and construction of tide gates and sea walls. On the other hand, DRR as a growing industry will prompt the emergence of disaster-specific investments, which then claim protection from foreign States under existing IIAs. Such investments might include early warning systems and data collection facilities in climate-vulnerable States; the development of drought-resistant agricultural technologies; critical infrastructure projects (e.g. to safeguard nuclear facilities from natural hazards); or social impact investments for adapting communities. Indeed, this may be an iterative and self-reinforcing process insofar as the international investment regime has been constructed to 'protect multinational corporations "from the control of developing states in their capacity to advance the interest of their public"' and is thus responsible for creating disaster risk. ${ }^{181}$

Further, disasters will draw out new avenues for legal argument within those claims. DRR as a policy imperative will provide a basis to challenge

181 Aronsson-Storrier ( $\mathrm{n}$ 3) 231, citing John Linarelli et al., The Misery of International Law (OUP 2018) 147. 
jurisdiction, as States invoke legality clauses to argue that statutory requirements to use fire-resistant materials to construct buildings, or to obtain special development approval for waterfront developments vulnerable to coastal erosion or rising tides, constitute 'fundamental laws of the host State' with which investors must comply at time of investing. The decision in Cortec leaves room for such an argument. They will also weigh more heavily on the merits. They will produce a wider range of investor claims than just the FET claims presented so far, including for a State's alleged failure to protect an investment from the physical impacts of a disaster (via an FPS claim), or discriminatory treatment of their investment before or during a disaster (via a discrimination claim), or even deprivations in its value owing to DRR or recovery measures (via an expropriation claim). On the State's side, they may give rise to counterclaims or be argued to engage customary defences, neither of which has occurred yet. Some analogous jurisprudence exists in the latter regard, in decisions which have considered the applicability of the customary defence of necessity in 'economic' states of emergency. ${ }^{182}$

Thirdly, one can project future jurisprudential trends by drawing a conceptual distinction between three kinds of "entry point". First, some disasters have raised complications - typically of procedure - whose resolution lies within the control of the parties (e.g. by agreeing to modify the procedural schedule or revert to virtual hearings). Secondly, other complications - again, typically of procedure - are governed by a tribunal's "unfettered" discretion: e.g. to grant a stay under Article 52(5) of the ICSID Convention, ${ }^{183}$ or to suspend hearings or postpone document production using a residual power to control arbitral procedure. Finally, disasters may create a complication governed by a defined legal standard or rubric. This category spans certain questions of procedure (e.g. the non-appearance of a witness for "valid reason", or the "good cause" required to depart from the principle of equal costs) and most questions of substance (e.g. whether "legality" of an investment requires compliance with a host State's DRR laws, or whether DRR constitutes an 'essential security interest' for the purposes of an NPM clause).

Of course, these legal standards are heterogenous in scope and definition, and may range from elastic to rigid. Nor are these categories mutually exclusive. The parties' consent may notionally resolve any procedural question. Article 44 of the ICSID Convention frames the parties' agreement as anterior to the application of default procedural rules or an exercise of the

182 See Odumosu-Ayanu (n 9).

183 Burlington Resources v. Ecuador (n 160) para. 70; see also Tethyan Copper v. Pakistan (n 166) paras. ${ }^{128-135 .}$ 
tribunal's discretion. Accordingly, the former category thus operates as a kind of bottleneck, in the sense that only in the absence of consent can procedural questions filter through to the latter two categories (which involve a tribunal determination).

Nonetheless, some observations follow from these distinctions. In firstcategory cases, party consent has provided enough flexibility to resolve complications created by disasters. Similarly, in second-category cases, tribunals have determined whether to factor disaster-related arguments and considerations into the exercise of their unfettered discretions, as appropriate in the circumstances at hand. Thus, both the principle of party autonomy and tribunal discretion over procedure are features of the investor-State arbitration system which enable it to adapt to the extraordinary circumstances generated by disasters. Arbitral institutions have assisted this, by publishing protocols (e.g. on virtual hearings during the COVID-19 pandemic) designed to guide tribunal discretion and to induce consensual modifications to procedure. ${ }^{184}$ Such complications are likely to remain manageable through pragmatic, ad hoc solutions - perhaps until we reach a tipping point in terms of the regularity of disasters, after which these ad hoc solutions become institutionalised defaults.

On the other hand, for third-category cases, tribunals have been required to reconcile disasters with a defined legal standard or rubric, with vastly different outcomes depending on the degree of elasticity of the rubric. Tribunals have treated certain legal standards as elastic enough to potentially accommodate modern policy developments that emphasise the importance of DRR - e.g. the jurisdictional requirement of "legality" in Cortec v. Kenya. Other tribunals, however, have regarded DRR measures to fall beyond the scope of their given standards, e.g. NPM clauses in Devas and Deutsche Telekom. For many other legal questions, tribunals have not yet been required to attempt to reconcile disaster policy with existing standards. Given this sparse and inconsistent jurisprudence, the future trajectory for such cases is uncertain. Their resolution will demand normative judgements on multiple levels - as to whether emerging norms of IDL should influence the interpretation of investment standards; and whether domestic DRR, response and/or recovery measures should be regarded as falling in a State's regulatory space.

For example, on the latter question, the timing of an impugned measure looms as significant. Some writers have suggested that ISDS challenges to COVID-19 response measures would fail because these measures fall within the scope of NPM clauses, carve-outs to substantive standards and/or customary

184 See (n 3o). 
defences. ${ }^{185}$ To be sure, this proposition may not hold across all State measures assessed under all IIAs. But even more obviously, the same conclusion would not necessarily follow for preventive measures taken in the name of DRR. As India's unsuccessful recourse to NPM clauses in Devas and Deutsche Telekom indicates, the relative inconspicuousness of DRR as a core regulatory imperative currently militates against its use as a knock-down defence.

Only as these kinds of judgements are made will it become apparent whether the investment arbitration framework is receptive to the imperatives that IDL seeks to emphasise. From this, we will be able to draw conclusions both about IDL's discursive impact, and about whether reform is necessary - to negotiation of IIAS, or interpretation of their standards, or even to the role of ISDS in toto - to reconcile the investment arbitration system with the needs of a warming world.

\section{4}

\section{Conclusion}

In sum, the trends identified in past jurisprudence represent the tip of a vast iceberg. On the one hand, these already-visible trends and factual scenarios will re-occur, and their corresponding lines of jurisprudence will develop. At the same time, a great number of novel procedural and substantive issues will also arise in time. The Covid-19 pandemic is a harbinger of these developments, not an anomaly. The limited jurisprudence so far has managed to resolve these challenges largely within the existing framework of procedural rules and investment treaty standards, without need for comprehensive adjustment. This may be easier for procedural challenges, given the broader role of consent and discretion in arbitral procedure, than substantive questions dependent on agreed BIT standards. But sterner tests await; and aspects of the framework may soon require reform, in order to imbue it with sufficient flexibility to cope with the exigencies of a warming world.

185 Julien Chaisse, 'Both Possible and Improbable - Could COVID-19 Measures Give Rise to Investor-State Disputes?' (2020) 13(1) Contemporary Asia Arbitration Journal 99; Prabhash Ranjan and Pushkar Anand, 'COVID-19, India, and investor-State dispute settlement (ISDS): will India be able to defend its public health measures?' (2020) 28(1) Asia Pacific Law Review 225. 